\title{
EFFECTS OF HUMIC ACIDS ON POULTRY UNDER STRESS CONDITIONS
}

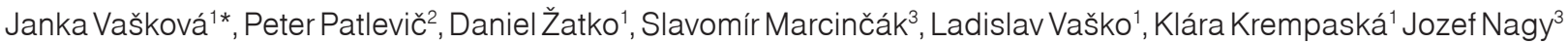 \\ ${ }^{1}$ Department of Medical and Clinical Biochemistry, Faculty of Medicine, Pavol Jozef Šafárik University in Košice, Tr. SNP 1, 04066 Košice, \\ ${ }^{2}$ Department of Ecology, Faculty of Humanities and Natural Science, University of Prešov, 17th November Street 1 , 08116 Prešov, \\ ${ }^{3}$ Department of Food Hygiene and Technology, University of Veterinary Medicine and Pharmacy in Košice, Komenského 73,04181 Košice, \\ Slovak Republic
}

*Corresponding author, E-mail: janka.vaskova@upjs.sk

\begin{abstract}
The transportation of chickens from the poultry farm to the slaughterhouse causes stress conditions that influence the oxidative status of the whole organism and subsequently change the organoleptic properties of the meat delivered to the consumer. The aim of this work was to investigate how administering $0.6 \%$ humic acids to broiler chickens for a period of 42 days affects the level of selected enzymes directly involved in oxidative stress elimination. For the most objective estimation of the oxidative state, parameters were determined in liver and kidney mitochondria, and in the blood plasma. With regards to the chelating properties of humic acids, our interest was in monitoring the effects on the distribution of the transition metals Fe, $\mathrm{Zn}, \mathrm{Cu}, \mathrm{Mn}$, which serve as cofactors of antioxidant enzymes. We have found that, under normal conditions, 42 days of humic acid administration do not cause significant metal redistribution. It has a significant effect on Se excretion, according to the pronounced deposition of Se in kidney tissue, without significantly increased activity of the corresponding enzyme. This led to compensation by changes in other antioxidant enzyme activities. This is a noteworthy finding, especially after administration of longer than 42 days. In conditions caused by sudden stress, according to the detected element levels, it is possible to expect a better response in the case of humic acid administration. The effect of humic acid supplementation appeared to be organ-specific and may ultimately be beneficial for the chickens' health, stress elimination and, finally, the quality of the meat.
\end{abstract}

Key words: antioxidant enzymes; humic acids; chicken; metal cofactors; oxidative stress

\section{Introduction}

Meat from poultry is deemed a suitable commodity for the production of functional foods for human consumption. This is currently of interest for human, agricultural and scientific research. From the perspective of the consumer, poultry is a very attractive and important element in the human diet due to its nutritional, dietetic, and sensory properties, and its rapid culinary preparation. Poultry consumption has risen dramatically across the world, including Slovakia. Thanks to modern factory farming,

Received: 20 June 2017

Accepted for publication: 7 November 2018 poultry production does not require a long period of fattening and can be purchased at any time. Achieving the most appropriate final quality of the meat is actually the purpose of all studies dealing with the impact of conditions to which it is exposed before reaching the final consumer.

Chickens slaughtered and processed in the meat processing industry are often transported a few hundred kilometres from a farm just before slaughter. However, even before the animals are slaughtered, they are subjected to a sequence of different events, such as cessation of feeding, capture, and placement in boxes or containers. Subsequently, broilers are transported to a slaughterhouse where they usually have to wait some time for slaughter (1). Transportation 
includes another set of stressors such as loading, social deprivation, restricted movement, vibration, noise, temperature, humidity, poor ventilation and often lack of food and water during transport, unloading, and subsequent handling in a new and unfamiliar environment. All of these factors compromise meat quality through formation of pale, soft and exudative meat or even death on arrival (2-5). The reaction of animals during transport depends on the length and intensity of the stressors and their physiological state (6). The animals respond to stress with changes in behaviour and in haematological, physiological, and neurohormonal parameters (7). The first reactions to stress are associated with enhanced secretion of a number of hormones including glucocorticoids, catecholamines, growth hormone and prolactin. The effect of this is to increase mobilisation of energy sources and help the individual adapt to its new circumstances (8). In particular, the enzymatic-mediated degradation of catecholamines by monoaminooxidases in mitochondria, as well as catecholamine autooxidation, contributes significantly to the increased levels of reactive oxygen species (ROS) under stress conditions. The mitochondria have their own elimination mechanisms against ROS, consisting of the enzymes superoxide dismutase (SOD), glutathione peroxidase (GPx), glutathione reductase (GR), and tripeptide glutamine (reduced form, GSH). The actions of these enzymes are particularly relevant to the function of mitochondria as an energy formation centre and also as a non-controllable source of ROS under stress conditions.

Humic acids (HAs) are structurally very complex high-molecular-weight natural compounds arising through the process of humification, which involves a number of biochemical reactions (9). Owing to their structure, HAs have the ability to interact with many compounds and structures in their natural environment (organic and inorganic molecules, ions, minerals and microbial surfaces) which are suitable for sorption, ion exchange, and biodegradation processes. They have a potential use in the detoxification of contaminants present in the environment (10). Humic substances have been shown to be an excellent means of reducing the bioavailability of hazardous substances. They may avert the formation of mutagenic and carcinogenic substances, protect DNA in cells from damage, and decrease the rate of gene mutation (11). The anti-viral, anti-inflammatory, anti-oxidant properties and binding properties of toxic substances have been well described in in vitro and in vivo systems $(12,13)$.

Since HAs have the ability to significantly influence the redox state of the body, there is also need to consider their chelating properties. The connection between these two properties in in vivo systems is yet to be described in the literature available. The aim of our study was therefore to determine the effects of the activities of antioxidant enzymes and levels of trace element co-factors after a 42-day supplementation of humic acids in normal breeding conditions and under stress conditions caused by transportation to the slaughterhouse.

\section{Materials and methods}

To verify the potential properties of HAs, the Vinica poultry farm in Velký Krtíš (Slovakia) was selected. This poultry farm is located $220 \mathrm{~km}$ from a poultry slaughterhouse in Košice. Chickens were fed conventional feed mixtures (FM) by corresponding growth phase (LUX DKAS, DKAGLUX 1, DKAG-LUX 2, DKAF LUX) and water ad libitum over 42 days. The entire brood was divided into two groups. The group without prophylactic doses of humic acids, designated as a control C, contained a total of 15,700 birds. The second group, identified as HA, consisted of a total of 20000 birds which had been fed conventional feed mixtures enriched with $6 \mathrm{~g} / \mathrm{kg}$ humic acid FM (Humac ${ }^{\circledR}$ Natur, Humac Ltd., Kosice, Slovakia) from the first day of fattening. All chicks were subjected to standard management and health. The chicks were randomly selected by three people for 10 birds from each group before and after transport to a slaughterhouse. Liver, kidney and plasma were collected. The mitochondria were isolated from parenchymatous organs according to Fernández-Vizzara et al. (14). In isolates and plasma, the activity of glutathione reductase (GR; E.C.1.6.4.2) was measured according to a method previously described by Calberg and Mannervik (15), while that of glutathione peroxidase (GPx; E.C. 1.11.1.9) was measured as described by Flohe and Gunzler (16). The measurements of SOD activities were provided by an SOD-Assay Kit-WST (Sigma-Aldrich, Switzerland) set. The levels of reduced glutathione were measured 
by the method previously described by Floreani et al. (17). All the measured parameters were calculated per $\mathrm{mg}$ or $\mathrm{g}$ of mitochondrial protein $\left(\mathrm{mg}_{\text {prot }}, \mathrm{g}_{\text {prot }}\right)$ determined using the bicinchoninic acid assay. The total content of zinc and iron was then determined by flame atomic absorption spectroscopy and that of copper, manganese and selenium by graphite furnace atomic absorption spectrometry (Shimadzu AA7000). The measured levels of elements were calculated to the value of $\mu \mathrm{g}$ (ng) per $\mathrm{mg}$ of proteins in mitochondrial homogenate or plasma. All measurements were performed in triplicate and the measured parameters are expressed as the mean \pm SD. Statistical significance between the two groups (C vs. HA) was determined using an unpaired Student's t-Test. Differences between the groups and bodies in the measured parameters were compared by one-way ANOVA followed by Tukey HSD test.

\section{Results}

The assessment of the activities of SOD revealed that a significant increase in activity was only detected in liver mitochondria when comparing control and HA groups after transportation (Figure $1)$.

A significant difference was also found between SOD activity in the liver of the control group prior to transportation and of the HA group after transport $(p=0.0074)$. In the mitochondria of the liver, kidney, and plasma of chickens prior to transport, significantly lower GPx activities were observed when HA was administered when compared to controls (Figure 2).

Multiple comparisons of groups revealed significant differences in GPx activity in the plasma of the group with HAs administered prior to transport and of the control group after transportation $(\mathrm{p}=0.0264)$ as well as between the two control groups $(p=0.0034)$. GR activity was analogous to GPx, significantly increased in the control group in liver mitochondria, before and after transport, and in the kidney mitochondria before transport. Also, multiple comparisons of groups showed significant differences in GR activity in plasma (Figure 3). These were observed between the control group and the HA group prior to transport $(p=0.0023)$, between the two control groups $(p=0.0366)$, between both groups with administered HA $(p=0.0002)$, and between the control group and HA group after transportation $(\mathrm{p}=0.0035)$.

Comparison of GSH concentrations revealed similarity between the significant changes in the activities of GPx and GR and the significant changes in plasma (Figure 4). Significant differences were found between the HA group prior to transport vs. the control group after transportation and between HA vs. controls after transport $(p=0.0001)$. Differences were also revealed between the control group and the HA group prior to transport and control group and HA group after transport at $\mathrm{p}=0.0057$ and $\mathrm{p}=$ 0.0068 , respectively.

The average concentrations of $\mathrm{Zn}, \mathrm{Cu}, \mathrm{Mn}, \mathrm{Fe}$, and Se were normalised to the protein content in the mitochondria of the liver, kidney and plasma. Differences between the control group and HA-administered chickens were found in the mitochondria and plasma for $\mathrm{Cu}, \mathrm{Mn}$, and Fe before and after transport (Table 1). Levels of metals showed specific changes. In the HA groups, concentrations of $\mathrm{Zn}$ were lower than in controls, whereas the copper concentration was increased after transport in the HA group. The concentrations of $\mathrm{Mn}, \mathrm{Fe}$ and Se generally declined after transport. Multiple comparisons of groups confirmed significant differences between the concentrations of elements in the HA group prior to transport, the control group after transportation, and the HA group after transportation (Table 1). The analyses of correlations between enzyme activities and concentrations of metals only showed strong positive correlation $(\mathrm{r}=0.8223)$ between the increasing concentrations of $\mathrm{Cu}$ and SOD activity.

The average carcass weight was lower in both groups prior to transport than after transport, but the \% yield was higher (Table 2). After transport, the HA group gave higher \% yield in comparison to control and the frequency of carcasses rejected from human consumption was significantly lower when compared to the control group.

\section{Discussion}

Previous studies experimenting with the addition of humic acids confirmed higher profitability and meat quality (18-20). With regards to the number of parameters that create 

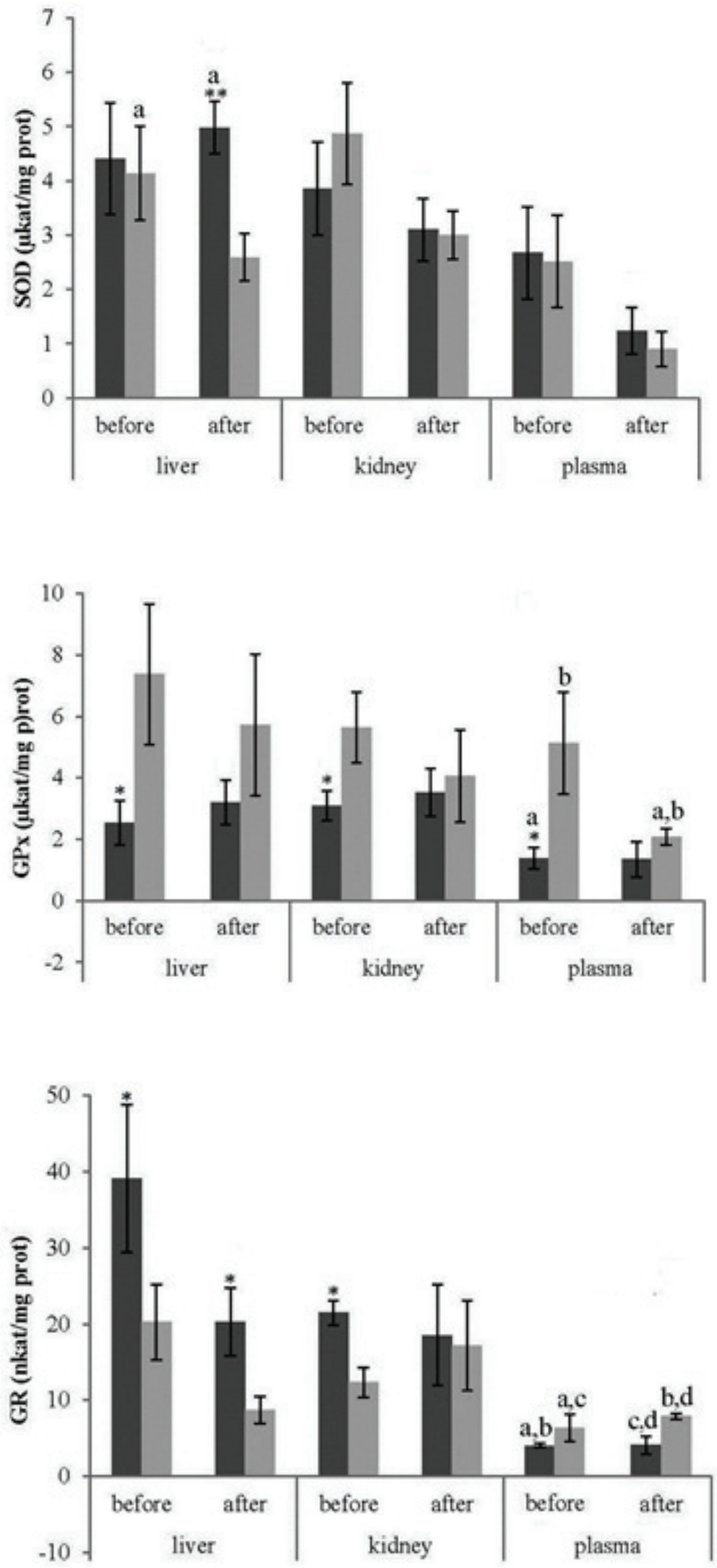

-HA

$=\mathrm{C}$

Figure 1: Superoxide dismutase activity measured in plasma, liver and kidney mitochondria before and after transport of chickens

Figure 2: Changes in glutathione peroxidase activities measured in control group and group administered with humic acids for 42 day before and after transport

- HA

$=\mathrm{C}$

Figure 3: Changes in glutathione reductase activities measured in control group and group administered with humic acids for 42 days before and after transport 
Figure 4: Reduced glutathione levels measured in plasma and liver and kidney mitochondria before and after stress from transport to the slaughterhouse

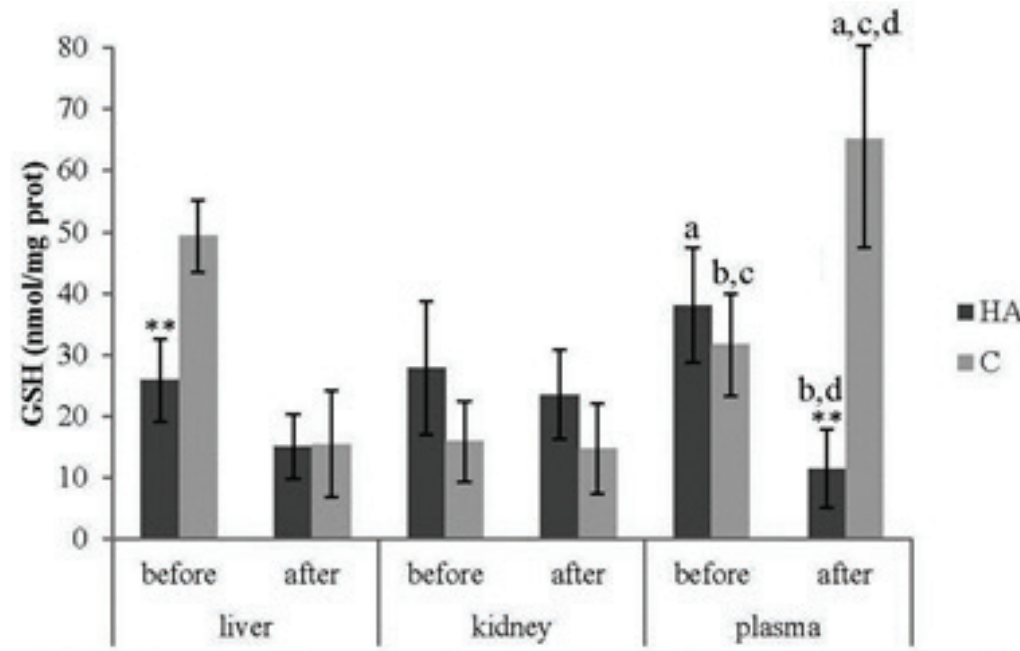

Table 1: Average values of trace elements measured in plasma, and liver and kidney mitochondria expressed per mg of protein

\begin{tabular}{|c|c|c|c|c|c|c|}
\hline & \multirow[t]{2}{*}{ Body } & \multicolumn{2}{|c|}{ Before transport } & \multicolumn{2}{|c|}{ After transport } & \multirow[t]{2}{*}{ Significance } \\
\hline & & $\mathrm{C}$ & HA & $\mathrm{C}$ & HA & \\
\hline \multirow{3}{*}{$\begin{array}{c}\mathrm{Zn} \\
(\mu \mathrm{g} / \mathrm{mg} \text { prot })\end{array}$} & liver & $2.199 \pm 0.155$ & $1.239 \pm 0.0819$ & $0.362 \pm 0.0098$ & $0.291 \pm 0.0517$ & \\
\hline & kidney & $1.365 \pm 0.0852$ & $0.650 \pm 0.0448$ & $0.253 \pm 0.0579$ & $1.223 \pm 0.0517^{*}$ & \\
\hline & plasma & $1.326 \pm 0.066$ & $1.180 \pm 0.0152^{\mathrm{a}}$ & $1.509 \pm 0.0349^{a, b}$ & $0.202 \pm 0.0101^{b}$ & $\begin{array}{l}{ }^{\mathrm{a}} \mathrm{p}=0.002 \\
{ }^{\mathrm{b}} \mathrm{p}=0.0042\end{array}$ \\
\hline \multirow{3}{*}{$\begin{array}{c}\mathrm{Cu} \\
\text { (ng/mg prot) }\end{array}$} & liver & $1.148 \pm 0.010$ & $2.769 \pm 0.0010^{* *}$ & $12.478 \pm 0.1965$ & $16.812 \pm 0.0412$ & \\
\hline & kidney & $2.010 \pm 0.0011$ & $1.230 \pm 0.0018^{* * * *}$ & $9.806 \pm 0.1368$ & $10.455 \pm 0.1024$ & \\
\hline & plasma & $1.134 \pm 0.0002$ & $1.103 \pm 0.0006^{* * * *}$ & $7.875 \pm 1.6756$ & $8.221 \pm 0.0419$ & \\
\hline \multirow{3}{*}{$\begin{array}{c}\mathrm{Mn} \\
\text { (ng/mg prot) }\end{array}$} & liver & $4.298 \pm 0.0038^{a}$ & $1.231 \pm 0.0076^{* * \mathrm{~b}, \mathrm{c}}$ & $0.004 \pm 0.0001^{\mathrm{b}}$ & $0.010 \pm 0.0002^{* * * a, c}$ & $\mathrm{a,b,c} p<0.001$ \\
\hline & kidney & $3.497 \pm 0.0179^{\mathrm{a}}$ & $1.037 \pm 0.0125^{* *}$ & $0.003 \pm 0.00001$ & $0.007 \pm 0.0001^{* * * a}$ & ${ }^{\mathrm{a}} \mathrm{p}<0.001$ \\
\hline & plasma & $0.981 \pm 0.0060$ & $1.393 \pm 0.0065^{* *}$ & $0.004 \pm 0.00001$ & $0.003 \pm 0.0001^{* * * *}$ & \\
\hline \multirow{3}{*}{$\begin{array}{c}\mathrm{Fe} \\
(\mu \mathrm{g} / \mathrm{mg} \text { prot })\end{array}$} & liver & $0.073 \pm 0.0028^{a}$ & $0.086 \pm 0.0005^{* * \mathrm{~b}, \mathrm{c}}$ & $0.004 \pm 0.0002^{\mathrm{b}}$ & $0.005 \pm 0.00011^{* * *_{a}, \mathrm{c}}$ & ${ }^{a, b, c} p<0.001$ \\
\hline & kidney & $0.022 \pm 0.0003^{a}$ & $0.066 \pm 0.0005^{* * *}$ & $0.003 \pm 0.00018$ & $0.004 \pm 0.00014^{* * * a}$ & ${ }^{\mathrm{a}} \mathrm{p}<0.001$ \\
\hline & plasma & $0.034 \pm 0.0007^{\mathrm{a}}$ & $0.075 \pm 0.0009^{* * *} \mathrm{~b}, \mathrm{c}$ & $0.004 \pm 0.00007^{\mathrm{b}}$ & $0.003 \pm 0.00015^{* * * a, c}$ & ${ }^{a, b, c} \mathrm{p}<0.001$ \\
\hline \multirow{3}{*}{$\begin{array}{c}\mathrm{Se} \\
\text { (ng/mg prot) }\end{array}$} & liver & under LOD & $1.278 \pm .00025$ & under LOD & $0.642 \pm 0.0004$ & \\
\hline & kidney & $2.945 \pm 0.0014$ & $25.921 \pm 0.0009^{* * *}$ & under LOD & $1.353 \pm 0.00004$ & \\
\hline & plasma & $11.899 \pm 0.0009$ & $3.907 \pm 0.0006^{* * * *}$ & under LOD & $1.524 \pm 0.0006$ & \\
\hline
\end{tabular}

${ }^{\text {*}}$ statistical significance of T-test comparison between control and HA group.

a,b,c Represent statistical significance between groups from multiple comparison by one-way ANOVA followed by Tukey post-hoc test.

Table 2: Comparison of some parameters before and after transport

\begin{tabular}{ccccc}
\hline Parameter & \multicolumn{2}{c}{ Before transport } & \multicolumn{3}{c}{ After transport } \\
& C & HA & C & HA \\
\hline Carcass yield $(\mathrm{g})$ & $1344.8 \pm 233.28$ & $1370 \pm 97.24$ & $1489 \pm 109.61$ & $1398 \pm 106,77$ \\
\% yield & $83.46 \pm 2.47$ & $80.83 \pm 4.16$ & $71.36 \pm 3.45$ & $73.98 \pm 3.21$ \\
Death on arrival & - & - & 18 & 39 \\
Carcass rejected from human consumption & 20 & 51 & 125 & 89 \\
\hline
\end{tabular}


stress conditions for birds before slaughter and consequently affect the quality of the meat, the transport of poultry to the place of slaughter is the one that is impossible to avoid. Cetin et al. (21) presented humic acids as a suitable supportive supplement in managing social stress. It is also worthwhile monitoring the parameters of antioxidant defence in central metabolically active organs as well as in circulation when assessing the effect of administered substances on the redox state of the organism. With regards to the site of distinctive ROS and energy generation, the mitochondria isolated from these organs have proved to be even more suitable for assessing redox status in poultry (22).

SOD activity was found to be significantly increased in liver mitochondria after transportation (Figure 1). The role of SODs against ROS is in the catalysis of the disproportionation of superoxide radicals $\left(\mathrm{O}_{2}{ }^{-}\right)$into $\mathrm{O}_{2}$ and $\mathrm{H}_{2} \mathrm{O}_{2}$. As $\mathrm{O}_{2}$ and $\mathrm{O}_{2}$ differ in a single electron, the enzyme must have a high specificity and be finely tuned to perform its catalytic role (23). Increased SOD activity after transport clearly indicates increased formation of $\mathrm{O}_{2} \cdot-$ in liver mitochondria. As transition metals have the ability to readily pick up and transmit electrons, they are very effectively used in ROS elimination reactions in the body. SOD is a collective term for a total of 3 unrelated enzymes that combine only the same catalytic activity. A localised form containing $\mathrm{Mn}$ is found in the mitochondrial matrix, while $\mathrm{Cu} / \mathrm{Zn}$-SOD is found in the cytosol, between the outer and inner membranes of the mitochondria, and in the extracellular space (24). Concentrations of metals were also measured and then normalised to the protein content in tissue samples taken. Extrapolation of the detected values to the activities of the enzymes measured which elements are contained in the active site, and provided an explanation of the nature of the effect of the administered substances. Concentrations of $\mathrm{Mn}$ in HA groups were lower compared to control and even more pronounced after transport (Table 1). At the same time, $\mathrm{Zn}$ concentrations were found to be decreased in HA groups, while copper concentrations increased, markedly so after transport (Table 1). The properties of Has, described by Mezes et al. (25), have shown that organic metal complexes, like HAs, have higher bioavailability. This is largely due to the structure that protects and stabilises trace elements in the passage through the gastrointestinal tract, allowing their passage through the intestinal wall via amino acid transport systems, and providing for a higher rate of passive diffusion due to lowered interaction with other nutrients. Although the high bivalent cation binding capacity of HAs improves their absorption, similar to Mezes et al. (25), we cannot confirm these properties after 42 days of HA administration, nor those of Herzig et al. (26). In part, this unexpected effect in the HA group without stress of transport is eliminated by the findings of Islam et al. (27), where concentrations of $\mathrm{Cu}$ and $\mathrm{Zn}$ were also reduced with recovery after 60 days. Under stress conditions, however, concentrations of $\mathrm{Mn}$ and especially $\mathrm{Cu}(\mathrm{Zn}$ in kidney mitochondria) are higher in the HA group when compared to stressed control and even the control group of unstressed birds (Table 1). In this situation, it is possible only to monitor the beneficial effect of HAs based on the nature of these enzymes. As Brown et al. (28) pointed out, $\mathrm{Cu} / \mathrm{Zn}$-containing SOD exists as an apoenzyme that is readily activated by copper without new protein synthesis. A copper-load form of copper chaperone has been shown as a higher order type of physiological regulation in response to oxidative stress (29), changing the enzyme disulphide status and forming an active dimer state. Binding of $\mathrm{Zn}$ ions is not essential for the dismutation reaction but confers higher stability (30). The same is not true for MnSOD, as Mn insertion only occurs with newly synthesized and imported molecules into mitochondria and it should stay sufficiently unfolded to allow $\mathrm{Mn}$ entry (31). After transport, there were generally lower concentrations of Mn. However, they were a little higher in the HA-administered stressed group than in stress control. The mechanism of maintaining this protein structure under stress conditions is not entirely clear. Despite the slight increase in $\mathrm{Mn}$ concentrations in mitochondria, there is a clear and apparent benefit in SOD activity support when administered with HAs, especially $\mathrm{Cu} / \mathrm{ZnSOD}$, under stress conditions.

The resulting product of dismutation $\mathrm{O}_{2} \cdot{ }^{-}$is hydrogen peroxide. This is the substrate for GPx, the next enzyme monitored. Essentially, in the catalytic cycle of all peroxidases, $\mathrm{H}_{2} \mathrm{O}_{2}$ is used as a specific electron acceptor, which is reduced to water. In terms of defence against oxidative stress, however, non-haem GPx catalyses the reduction of $\mathrm{H}_{2} \mathrm{O}_{2}$ or organic peroxides to water or corresponding alcohols, with the simultaneous oxidation of GSH 
playing an important role. The oxidised glutathione is subsequently reduced by the catalytic activity of GR. Taking these three parameters together allows a more objective assessment of antioxidant efficiency. Some GPx isoforms with specific distribution between tissues and subcellular compartments (cytosol, nucleus, mitochondria, plasma) contain selenium in their catalytic centre. The distribution of these selenoenzymes affects the level of ROS, the relative level of glycolysis in ratio to oxidative phosphorylation, the level of redox-sensitive transcription factors, and the resulting rate of important cellular processes (32). In humans, endemic diseases and increased virulence of coxsackie virus have been linked to selenium deficiency, and high concentrations of humic acids in drinking water among other possible etiological factors (33). Therefore, it was interesting to compare GPx activity and Se levels. According to these measurements, it is obvious that the activities of GPx were significantly lowered when administered with HA and stress-free (Figure 2). Concentrations of Se, however, were markedly increased in the kidney (Table 1, before transport). After the effect of transport stress, GPx activity was lower but without prominence in liver and kidney mitochondria, and the Se concentration remained measurable unlike in controls. Considering the changes in GR activity (Figure 3) and GSH levels (Figure 4), it cannot be assumed that oxidative stress conditions have been created. Through the action of a stressor, differences are no longer statistically significant, except for GR in liver. These in vivo results confirm the antioxidant activity of HA in mitochondria under in vitro conditions (13). Due to higher Se concentrations upon HA administration, it can be assumed that the effect of HA is through maintaining the activities of Se-GPx isoforms in mitochondria. Significant differences in all three parameters were only found comparing groups in plasma, which ultimately resulted in markedly reduced levels of reduced glutathione in the stressed group administered with HA (Figure 4).

Interestingly, lower Se concentrations were detected in the plasma following administration of HA versus control, still without changes in plasma GPx activity. After stress from transport, however, the highest Se concentration was found in plasma. Kidneys are the main location for the synthesis of selenium-containing GPx before its secretion into plasma and extracellular fluids
(34). Therefore, as an explanation we can state that humic acids used in this study did not cause deficiency but increased the bioavailability of Se. Se accumulates in the kidney and is likely to allow for the synthesis of Se-GPx isoforms under stress conditions. Still, levels of reduced GSH were significantly lowered in plasma in the HA group after transport. The liver is the main source of GSH in circulation, followed by complicated interorgan transfer. Circulating GSH and GSSH are particularly used by the kidneys (35). That could be one of the possible explanations for the renal load of Se after HA administration. According to results of copper concentrations in connection with SOD, it seems more appropriate that its role lies in the metabolism of copper ions for the biosynthesis of copper-containing proteins (36). GSH serves as a carrier for $\mathrm{Cu}^{+}$, and is involved in copper mobilisation with the complex $\mathrm{Cu}(\mathrm{I})$ GSH being used for incorporation into $\mathrm{Cu} / \mathrm{Zn}$ SOD (37). This explanation is also supported by a strong positive correlation between the increased concentration of $\mathrm{Cu}$ and SOD activity.

Significantly elevated $\mathrm{Fe}$ concentrations were found after administration of HAs in both mitochondria and plasma, which is consistent with the findings of Ipek et al. (38) and the described properties of HA. After transport, Fe concentrations decreased in both monitored groups. Regarding the measured parameters, oxidative stress conditions are not created due to $\mathrm{Fe}$ concentrations, and its bioavailability is associated with better use.

Overall, the administration of humic acids at $0.6 \%$ in feed mixtures over 42 days is considered to be beneficial for stress from transport, since oxidative stress conditions have not been demonstrated in the main organs responsible for nutrient metabolism and energy production. Finally, in terms of losses and meat excluded from consumption, the group with HAs fared better. According to measurements of metals, we cannot fail to notice the rapid differences between mitochondrial concentrations caused by stress, which have yet to be mentioned at all. However, based on the results, HAs administered as feeding additives are shown to cause metal redistribution in terms of the unexpected requirements of the organism. 


\section{Acknowledgements}

The study was supported by grants of Scientific Grant Agency of the Ministry of Education, Science, Research and Sport of the Slovak Republic no. $1 / 1236 / 12$ and $1 / 0782 / 15$.

\section{References}

1. Nijda E, Arens P, Lambooij E, et al. Factors influencing bruise and mortality of broilers during catching, transport and lairage. Poultry Sci 2004; 83: $1610-5$.

2. Oba A, de Almeida M, Pinhero JW, et al. The effect of management of transport and lairage conditions on broiler chicken breast meat quality and DOA (Death on Arrival). Braz Arch Biol Technol 2011; 52: 205-11.

3. Lengkey HAW, Siwi JA, Edianingsih P, et al. The effects of transportation on broiler meat $\mathrm{pH}$ and tenderness. Biotech Anim Husbandry 2013; 29: 331-6.

4. Zhu Z, Chen Y, Huang $Z$, et al. Effects of transport stress and rest before slaughter on blood parameters and meat quality of ducks. Can J Anim Sci 2014; 94: 595-600.

5. Doktor J, Połtowicz K. Effect of transport to the slaughterhouse on stress indicators and meat quality of broiler chickens. Ann Anim Sci 2009; 9: 307-17.

6. Southern KJ, Rasekh JG, Hemphill FE, et al. Conditions of transfer and quality of food. Rev Sci Tech 2006; 25: 675-84.

7. Fazio E, Ferlazzo A. Evaluation of stress during transport. Vet Res Commun 2003; 27: 519-24.

8. Ranabir S, Reetu K. Stress and hormones. Indian J Endocrinol Metab 2011; 15: 18-22.

9. Tan KH. Humic matter in soil and the environment: principles and cntroversies. New York : Marcel Dekker, 2003: 408.

10. Skokanová M, Dercová K. Humínové kyseliny. Interakcie humínových kyselín s kontaminantami. Chem Listy 2008; 102: 338-45.

11. Perminova IV, Hatfield K. Remediation chemistry of humic substances: theory and implications for technology. In: Perminova IV, ed. Use of humic substances to remediate polluted enviroments: from theory to practice. Dordrecht : Springer, 2005: 3-36.

12. van Rensburg CE. The antiinflammatory properties of humic substances: a mini review.
Phytother Res 2015; 29: 791-5.

13. Vašková J, Veliká B, Pilátová $M$, et al. Effects of humic acids in vitro. In Vitro Cell Dev Biol Anim 2011; 47: 376-82.

14. Fernández-Vizarra E, Ferrín G, Pérez-Martos A, et al. Isolation of mitochondria for biogenetical studies: an update. Mitochondrion 2010; 10: 253-62.

15. Carlberg I, Mannervik B. Glutathione reductase. Methods Enzymol 1985; 113: 484-90.

16. Flohé L, Gunzler WA. Assays of glutathione peroxidase. Methods Enzymol 1984; 105: 114-21.

17. Floreani M, Petrone M, Debetto P, et al. A comparison between different methods for the determination of reduced and oxidized glutathione in mammalian tissues. Free Radic Res 1997; 26: 449-55.

18. Ozturk E, Coskun I, Ocak N, et al. Performance, meat quality, meat mineral contents and caecal microbial population responses to humic substances administered in drinking water in broilers. Br Poult Sci 2014; 55: 668-74.

19. Ozturk E, Ocak N, Turan A, et al. Performance, carcass, gastrointestinal tract and meat quality traits and selected blood parameters of broilers fed diets supplemented with humic substances. J Sci Food Agric 2012; 92: 59-65.

20. Nagaraju R, Reddy BS, Gloridoss R, et al. Effect of dietary supplementation of humic acids on performance of broilers. Indian $\mathrm{J}$ Anim Sci 2014; 84: 447-52.

21. Cetin E, Berrin KG, Nazmi C. Effect of dietary humate and organic acid supplementation on social stress induced by high stocking density in laying hens. J Anim Vet Adv 2011; 10: 2402-7.

22. Fejerčáková A, Vašková J, Bača $M$, et al. Effect of dietary microbially produced gamma-linolenic acid and plant extracts on enzymatic and non-enzymatic antioxidants in various broiler chicken organs. J Anim Physiol Anim Nutr 2014; 98: 860-6.

23. Perry JJ, Shin DS, Getzoff ED, et al. The structural biochemistry of the superoxide dismutases. Biochim Biophys Acta 2010; 1804: 245-62.

24. Miriyala S, Spasojevic I, Tovmasyan A, et al. Manganese superoxide dismutase, MnSOD and its mimics. Biochim Biophys Acta 2012; 1822: 794-814.

25. Mezes M, Erdelyi M, Balogh K. Deposition of organic trace metal complexes as feed additives in farm animals. Eur Chem Bull C 2012; 1: 410-3.

26. Herzig I, Navrátilová M, Totušek J, et al. 
The effect of humic acid on zinc accumulation in chicken broiler tissues. Czech J Anim Sci 2009; 54: 121-7.

27. Islam KM, Schuhmacher SA, Gropp MJ. Humic acid substances in animal agriculture. $\mathrm{Pa}-$ kistan J Nutr 2005; 4: 126-34.

28. Brown NM, Torres AS, Doan PE, et al. Oxygen and the copper chaperone CCS regulate posttranslational activation of $\mathrm{Cu}, \mathrm{Zn}$ superoxide dismutase. Proc Natl Acad Sci U S A 2004; 101: 5518-23.

29. Culotta VC, Yang M, O'Halloran TV. Activation of superoxide dismutases: putting the metal to the pedal. Biochim Biophys Acta 2006; 1763: 747-58.

30. Furukawa Y, Torres AS, O'Halloran TV. Oxygen-induced maturation of SOD1: a key role for disulfide formation by the copper chaperone CCS. EMBO J 2004; 23: 2872-81.

31. Luk E, Yang M, Jensen LT, et al. Manganese activation of superoxide dismutase 2 in the mitochondria of Saccharomyces cerevisiae. J Biol Chem 2005; 280: 22715-20.

32. Bera S, Weinberg F, Ekoue DN, et al. Natural allelic variations in glutathione peroxidase-1 affect its subcellular localization and func- tion. Cancer Res 2014; 74: 5118-26.

33. Farooq U, Xiong G, Irshad R, et al. Pattern of joints involvement in Kashin-Beck disease: a local osteochondropathy in China. Ayub Med Coll Abbottabad 2010; 22: 97-100.

34. Avissar N, Ornt DB, Yagil Y, et al. Human kidney proximal tubules are the main source of plasma glutathione peroxidase. Am J Physiol 1994; 226: C367-75.

35. Lushckak V. Glutathione homeostasis and functions: potential targets for medical interventions. J Amino Acids 2012; 2012 (Art. ID 736837): e1-2. https://www.hindawi.com/journals/jaa/2012/736837 (June 2017)

36. Wang W, Ballatori N. Endogenous glutathione conjugates: occurrence and biological functions. Pharmacol Rev 1998; 50: 335-56.

37. DiDonato M, Sarkar B. Copper transport and its alterations in Menkes and Wilson diseases. Biochim Biophys Acta 1997; 1360: 3-16.

38. Ipek $H$, Avci M, Iriadam M, et al. Effects of humic acid on some hematological parameters, total antioxidant capacity and laying performance in Japanese quails. Arch Geflügelkd 2008; 72: 56-60.

\title{
UČINKI HUMINSKE KISLINE NA PERUTNINO V STRESNIH POGOJIH
}

\author{
J. Vašková, P. Patlevič, D. Žatko, S. Marcinčák, L. Vaško, K. Krempaská, J. Nagy
}

Povzetek: Prevoz piščancev s perutninske farmev klavnico povzroča stresne razmere, ki vplivajo na oksidativni status celotnega organizma in kasneje spremenijo organoleptične lastnosti mesa, dostavljenega potrošniku. Cilj raziskave je bil proučiti, ali dodajanje 0,6 \% huminske kisline v hrano pitovnim piščancem za 42 dni vpliva na aktivnost nekaterih encimov, ki so neposredno vključeni v urejanje in zmanjševanje oksidativnega stresa. Za objektivno ocenjevanje oksidativnega stanja so se določevali parametri v jetrnih in ledvičnih mitohondrijih ter v krvni plazmi. Kelacijske lastnosti huminske kisline so bile proučevane s spremljanjem učinkov na porazdelitev prehodnih kovin $\mathrm{Fe}, \mathrm{Zn}, \mathrm{Cu}, \mathrm{Mn}$, ki služijo kot kofaktorji antioksidantnih encimov. Ugotovili so, da vnormalnih pogojih 42-dnevno dodajanje huminske kisline ne povzroči bistvene prerazporeditve kovin. Dodajanje pa pomembno vpliva na izločanje Se glede na izrazito usedlino Se vtkivu ledvic, brez bistveno povečane aktivnosti ustreznega encima. To je privedlo do sprememb, ki so nadomestile aktivnosti drugih antioksidantnih encimov. To je pomembna ugotovitev, še posebej pri dodajanjih več kot 42 dni. V pogojih, ki jih povzroča nenadni stres, je glede na ugotovljene ravni elementov mogoče pričakovati boljši odziv pri uporabi huminske kisline. Učinek dopolnjevanja s huminsko kislino se je izkazal za organsko-specifičnega in je lahko koristen za zdravje piščancev, odpravo stresa in končno kakovost mesa.

Ključne besede: antioksidativni encimi; humične kisline; piščanec; kovinski kofaktorji; oksidativni stres 